THE ILLICIT ADVENTURES OF RAWLINSON1 British Intelligence in the Final Phase of the Ottoman Empire

\title{
BÜLENT GÖKAY
}

Historians have usually tended either to ignore intelligence altogether or to treat it as of little importance. Many important accounts of the 20th century political history do not even mention the names of the intelligence services. This can partly be explained by the difficulty of researching the intelligence records. The bulk of the relevant records have been destroyed or else retained indefinitely by the governments. It is not easy to redress the balance. Only a careful search of the papers can produce even a fragmentary run of documents on the topic. There is also a desire not to be regarded as on the same level as the inaccurate sensationalism of many bestselling accounts of espionage.

Intelligence does not win wars. It does not shape foreign policy. Nonetheless, intelligence activities are an inseparable part of the policymaking process. On might think of the intelligence game conducted in the context of various paradigms of international relations. It is one cog in the mighty machine of command, an accessory to help the commander make decisions.

In this paper I will concentrate on a particular example in the field of military intelligence. In general terms, military intelligence is charged with gathering and evaluating information about the enemy whilst preventing him from discovering what your own forces are doing.

\footnotetext{
${ }^{1}$ This is a revised version of the paper presented in the Seminar on "Spying in the Ottoman Empire", the Skilliter Centre for Ottoman Studies, Newnham College, Cambridge, 29 April 1995.
} 
The accelerated pace of historical change and technological innovation have generated new forms of estrangement that can no longer be fully understood or adequately mediated by traditional intellectual and diplomatic practices. The development of military technology, the improvement of warships, firearms and field artillery, created a growing need for intelligence concerning the nature of military operations.

At the end of the 19th century the first purely military intelligence organisations in the modern sense emerged. The 20th century witnessed increasingly evident links between the development of science and technology, the changing nature of warfare and the increasing role of intelligence. This interaction became clearly visible in the First World War. The growing use of advanced technology in warfare went hand in hand with the increasing relevance of technology for intelligence collection.

With the outbreak of the First World War ad hoc "Intelligence Corps" were established within the British Forces, first in the Western Front. The "Intelligence Corps" proved so successful that, as the war expanded, other Intelligence Corps or special branches were formed in most theatres. These theatre intelligence units varied in size and organisation according to local needs.

Wartime intelligence organisation in the lands of the Ottoman Empire was almost as confused as the empire itself. At the beginning of the war, one of the most complex tasks of intelligence for the British forces was the collection and assessment of material on the Turkish Army in the Middle East. This theatre was vast and the needs for intelligence was considered exceptionally pressuring. The Turks had small forces fighting the British, but large reserves in Anatolia. Even if one could acquire complete knowledge of the Turkish army's order of battle and intentions and determine the location and movement of every single Turkish division, further problems were at hand. Turkish formations were often identified only by the name of their commander. 'So-and-so's force' might be a regiment or a corps, and its identification was changed without warning.

The Turkish Army, moreover, was organised with less regularity than those of western Europe. In December 1915, for instance, the British commander in Egypt wrote that "all calculations as to what the Turks and Arabs can or cannot do generally are wrong; it is impossible to get any information of what is being done in regard to preparations". 2

\footnotetext{
${ }^{2}$ Maxwell to Kitchener, 11 December 1915 , given by J. Ferris, ed., The British Army and Signals Intelligence During the First World War, Stroug-Gloucestershire, 1992, p. 297.
} 
The British did not have a unified system of intelligence within the Ottoman Empire. Indeed, the Viceroy Lord Lytton had criticised the lack of a British secret service in Istanbul as long ago as $1878 .^{3}$ By 1914 , the Secret Service Bureau (the predecessor of M16) did not operate inside the Ottoman Empire. Various local agencies on the periphery of the Ottoman Empire provided intelligence. The military attachés dealt mainly with European Turkey where the bulk of the Ottoman Army was concentrated. The Intelligence Bureau of the Egyptian War Office covered Sinai and the Levant coast. And the British depended on the Russian General Staff in the Caucasus for information on the Turkish Army Group based at Erzurum.

The lack of signals intelligence on the Turkish Army in the early part of the war made human intelligence all the more vital. However, agent networks within the Ottoman Empire were particularly unreliable. Transport was slow and news took time to come through. Moreover, the Turks had a great advantage in possessing internal lines of communications.

The Ottoman Empire was not a soft target for British intelligence. The Turkish authorities were vigilant and penalties for spying severe. There were a number of incidents involving the capture and execution of British spies in Anatolia during and after the First World War. ${ }^{4}$

As the war progressed, various improvements were effected in the British espionage organisation in the lands of the Ottoman Empire. The capability of British intelligence progressively improved. The intelligence network developed, and the intelligence picture became more accurate.

The means of the filed intelligence at the disposal of the Mesopotamian Expeditionary Force improved over the course of the war. At the end of 1917 a separate Intelligence Corps was formed for the Salonika Force, which later became the Army of the Black Sea. This Corps recruited a large number of British subjects living in the Levant who spoke Greek and Turkish fluently.

After the separate armistices with Bulgaria in September 1918 and Turkey in the following month, officers were made responsible for seeing that the terms of armistice agreements relating to such things as disarmament and demobilisation were properly carried out. This was reckoned to be one of the functions of General Staff Intelligence officers. Such officers came to be known as 'control officers'. Subsequently, more control officers were sent to

${ }^{3}$ Letter from Lytton to Staplehurst, 27 April 1878, in M. Handel, ed., Intelligence and Military Operations, London, 1990, p. 141.

${ }^{4}$ B. Gökay, "Ankara'da Bir Ingiliz Casusu", [A British Spy in Ankara], Tarih ve Toplum, No. 98, February 1992. 
the Caucasus to supervise the evacuation of German and Turkish troops there.

The resurgence of Turkish nationalism in 1919 had created further Intelligence requirements. Marshall Cornwall was chosen to become Special Intelligence Officer to the Commander-in-Chief, General Sir Charles Harrington, in 1921. Marshall Cornwall was tasked with the surveillance of all Turkish military activity. He ran a small network of agents. Of his work he later wrote: "In fact one of Mustafa Kemal's senior officers has been in my pay for months and we were fully informed about the Nationalist order of battle. ${ }^{5}$

The greater part of the credit for the relative success in this undertaking belongs to a small number of intelligence officers who almost single-handedly dominated the local affairs by virtue of their charisma and standing.

Colonel Rawlinson provides a unique example for the intelligence activities in this period. His activities cover the whole period from 1918 to 1922. His adventures, such as are known, are almost incredible. Rawlinson, in the Caucasus and Eastern Anatolia, sped from village to village in his Ford car, enforcing his will either by wise words or by fierce beatings with stick or first. Rawlinson was a dedicated intelligence officer who had already travelled widely over some of the roughest country in the region and among some of toughest peoples.

Colonel Alfred Rawlinson was the son of Sir Henry Rawlinson who had been one of the leading players in the 19th century 'Great Game'. 6 Perhaps. Rawlinson had inherited his father's taste for risky exploits.

\section{Rawlinson in the Caucasus:}

Rawlinson first came to the region in June 1918, part of an expeditionary force in Northern Iraq. The disintegration of the Russian armies following the Bolshevik Revolution of November 1917 had created a large and totally undefended gap in the Caucasus. This special force, known as the 'Hush-Hush' Army, was trying to control this area and prevent the German and Ottoman forces from putting the strategic locations in the region under their control.

\footnotetext{
${ }^{5}$ Marshall-Cornwall, Wars, pp. 59-60.

${ }^{6}$ Colonel Rawlinson desribes his father as "the famous archaelogist, the original decipherer of the dead cuneiform language and the last surviving director of the old East India Company." (A. Rawlinson, Adventures in the Near East, London and New York, 1923, p. 26).
} 
These operations were directed by Major-General Lionel C. Dunsterville, the hero of Kipling's novel Stalky and Co. ${ }^{7}$ Dunsterville had been appointed chief of the British mission to the Caucasus and also British representative at Tiflis in January 1918. ${ }^{8}$ His sphere of work was to extend over all Russian and Turkish territories south of the main chain of the Caucasus. The primary military objective of Dunsterville's mission was defined as "the maintenance of an effective force on the Caucasus front so as to protect the occupied portions of Turkish Armenia and to prevent the realisation of Pan-Turanian designs". 9 To achieve this objective Dunsterville was to cross the 650 miles between Baghdad and Enzeli and from there to embark his men for Baku and Tiflis. ${ }^{10}$

The preparations for Dunsterville's advance in the Caucasus were undertaken by a small number of British military intelligence officers who by then had set up a committee in Tiflis called the 'Caucasus Military Agency'. ${ }^{11}$

Starting from early June, Turkish troops were coming closer to the line Dunsterville was trying to hold. ${ }^{12}$ The Turkish army was rapidly advancing towards Baku and the city was surrounded by mid-June. In the face of this danger, the Hush-Hush army was ordered to send a total of two British battalions, with supporting artillery and armoured cars, to Baku. ${ }^{13}$ Among

${ }^{7}$ Kipling and Dunsterville had shared a study at the public school Westward Ho in 1880. (Carrington, The Life of Rudyard Kipling, p. 22.)

${ }^{8}$ Ronald MacDonell, the British vice-consul in Baku, writes in his memoirs that there were a number of British Intelligence Officers in the Caucasus, whose duties "were to prepare, devise or create a situation which would enable General Dunsterville and his force to take charge." (MacDonell, And Nothing Long, p. 205).

${ }^{9}$ Moberly, History of the Great War Based on Official Documents, the Campaign in Mesopotamia, 1914-1918, IV, pp. 104-105.

${ }^{10}$ Dunsterville, The Adventures of Dunsterforce, pp. 11-67.

${ }^{11}$ Major Goldsmith describes his activities with the Caucasus Military Agency in his 86-page report to the Director of Military Intelligence. Goldsmith spent eight months in the region until 6 October 1918 when he and the other members of the Caucasus Military Agency were arrested by the Bosheviks in Vladikavkaz. (From Major G.M. Goldsmith, Acting British Military Agent, Army of Caucasus Front to the Director of Military Intelligence, W.O., 1 July 1919; London, PRO; WO 95/4960.)

${ }^{12}$ From Sir C. Greene (Tokyo) to Balfour, 12 June 1918; London, PRO; FO $371 / 3292$.

13 Moberly, History of the Great War Based on Official Documents, the Campaign in Mesopotamia, IV, pp. 198-199. 
those was Colonel Rawlinson who was given the title of 'Controller General of the Ordenance' of the Transcaucasus. ${ }^{14}$

However, this small force was totally inadequate even for the purpose of compelling the Turks to raise the siege of Baku. ${ }^{15}$ And on the night of 14 September, with Baku under heavy attack, Dunsterville loaded his men on ships and left the city to its fate. Rawlinson managed to load most of the ammunition on to a little ship and left the city with large quantities of explosive. This was the only success of the mission. ${ }^{16}$

\section{Intelligence in Eastern Anatolia:}

After playing a significant role in the unsuccessful defence of Baku against the Turkish armies in August-September 1918, Rawlinson had left Baku with Dunsterville and returned to London soon after. "Having been just under three months at home", he had been sent back to the Caucasus in February $1919 .{ }^{17}$ This time he had been ordered to base himself in Tiflis as a 'Special Service Officer' under the orders of General Beach, who was then in charge of British Intelligence in the Caucasus. ${ }^{18}$

By then the First World War had finished. The Ottoman and German troops had already left the Caucasus. But this time there were the Russiam Bolsheviks trying to establish their power in the lands of the Caucasus. In

${ }^{14}$ Rawlinson, Adventures in the Near East, pp. 67-69.

15 Moberly writes that the Turks opposite Baku numbered 5,300 regulars with 26 guns and 8,000 Tatar irregulars under Turkish officers. (Moberly, History of the Great War Based on Offical Documents, the Campaign in Mesopotamia, IV, p. 230.)

${ }^{16}$ MacDonell, And Nothing Long, p. 265. The Caucasus Military Agency, on the other hand, had been transferred to Vladikavkaz when the Turkish armies approached the Tiflis area. There Colonel Pike was accidentally shot on 15 August while watching the street battles between the Bolsheviks and the Terek Cossacks. Goldsmith, who after the death of Pike became the Acting Commanding Officer of the Caucasus Military Agency, and the other members of the mission were arrested in Vladikavkaz by the Bolsheviks in October for being connected with the Lockhart conspiracy. Lockhart was then under arrest in Moscow for engineering a counter-revolutionary plot and was eventually sentenced to death. ('Secret and Confidential Memorandum on the Alleged "Allied Conspiracy" in Russia', 5 November 1918; London, PRO; FO 371/3348.) Members of the Caucasus Military Agency were sent to Moscow in January 1919 and stayed in Butirski prison until July 1919. (Goldsmith's Report to the Director of Military Intelligence, 1 July 1919; London, PRO; WO 95/4960.)

${ }^{17}$ Rawlinson, Adventures in the Near East, p. 109.

18 Ibid., p. 113. 
Anatolia, too, there was a recently emerged nationalist movement. These two anti-British forces, Turkish natiohalists and the Russian Bolsheviks, were cooperating in the Caucasus and eastern Anatolia. In this new situation, Rawlinson was ordered to concentrate his activities in northeastern Anatolia to prevent any further collaboration between the Bolsheviks and the Turkish nationalists.

The early months of 1919 had been quite busy for Rawlinson who tried to set up an intelligence network in the region between Trabzon, Erzurum and Kars. He had arrived in Erzurum about the same time as the new Turkish army commander Kazım Karabekir. ${ }^{19}$

In Erzurum Rawlinson maintained unofficial pourparlers with the leading nationalists, and local officers. He even had a brief conversation with Mustafa Kemâl who was in Erzurum for the nationalist congress of July $1919 .{ }^{20}$ On a number of occasions he tried to win Kazım Karabekir over to the cause of building a mighty barrier in the Caucasus to confront the Bolshevik armies.

Rawlinson, in his memoirs, does not make any direct reference to the contents of his discussions with Karabekir. He recalls the talks only by saying that "we had...many discussions with reference to Russia and her future..." 21 Nevertheless, we have enough material in the form of memoirs of activists of this period, including those of Karabekir, to reconstruct basic framework of the Rawlinson-Karabekir talks. Karabekir was asked on several occasions to act in the region against the Bolsheviks.

British attempts to convince the Turks to take an anti-Bolshevik stand in the Caucasus failed because the British did not, and could not, offer any firm and substantial guarantee to the Turks. Karabekir gave the issue serious consideration and circulated the demands of Rawlinson to the other nationalist leaders. But first he wanted to see some solid evidence of the British commitment. The British proposals were, however, clearly self-serving and possibly suspect in their eagerness to foster the idea of British-Turkish cooperation against Boshevism. Karabekir finally came to the conclusion that

${ }^{19}$ Ibid., pp. 148-9. Rawlinson describes in his memoirs his first impression of this important fortress which stands in the shelter of mountains at a height of 7,000 feet: "The winds there blow with terrific force, and the piercing cold defies all furs...No tree or shrub of any sort can be found within over 50 miles, either to afford fuel when cut or shelter of any kind, and the words 'dismal', 'dreary', 'desolate', and 'damnable', suggest themselves irresistable as a concise description of the whole locality." (Ibid., p. 180).

20 Ibid., p. 156.

21 Ibid., p. 221. 
the British had neither a clear policy nor the means to support an antiBolshevik Caucasian barrier. ${ }^{22}$ In his telegram to Mustafa Kemâl, dated 14 February 1920, Karabekir expressed his deep suspicion: "How could the Allies talk about the formation of a Caucasian barrier when they had no military power in the region". 23

It appears that Rawlinson's efforts achieved the reverse of his intention. They strengthened the belief on the Turkish side that, compared with the Bolsheviks, the British neither had the political commitment, nor the necessary means to support their offers. After his meetings with Rawlinson, Karabekir concluded that the strategic position of the Turks in the region was an effective weapon which could be used skillfully against the British. Without compromising his cautious approach to the Bolsheviks, Karabekir sent a number of instructions to his contacts in Azerbaijan and Daghestan and urged them not to become involved in any British conspiracy against the Bolsheviks. ${ }^{24}$

\section{Rawlinson in Prison:}

The same winter months of 1919-1920, when the British fortunes in the Caucasus were at a low ebb and things were beginning to look up for the Bolsheviks, witnessed the emergence of quite serious opposition to British control in Turkey. The profile of the Turkish national movement was rising rapidly in both Anatolia and in the capital.

A number of options were put forward by the British in February and March 1920 to prevent the situation from deteriorating any further. A military solution to stop the Bolsheviks in the Caucasus had already been "reluctantly dropped"-partly because of the "difficulty in finding the necessary troops". 25 There was anxiety about the security of British positions in Turkey. Under such circumstances it was considered necessary to call more troops to the Ottoman capital to ensure the security of the existing British forces. ${ }^{26}$

22 Ibid., pp. 440-1, and 444.

${ }^{23}$ Cited in Yerasimos, Türk-Sovyet Iliş̧kileri, p. 121. British forces (apart from a garrison in Batum) had been withdrawn from the Caucasus by the end of September 1919.

${ }^{24}$ Karabekir, Istiklâl Harbimiz, pp. 492-493.

25 Admiral de Robeck to the Secretary of Admiralty, 18 March 1920; London, PRO; FO 371/5046.

${ }^{26}$ From High Commissioner (Constantinople) to the FO, 11 March 1920; London, PRO; E 1357/3/44 FO 371/5043. 
Finally, the Allied Supreme Council decided on a reinforced occupation of the Ottoman capital and firm control over the Straits. ${ }^{27}$ On 16 March 1920, the Allied corps under the orders of Lieutenant General Sir Henry Wilson entered the Turkish quarters of the town and arrested leading Kemalists - together with other suspected nationalists and communist activists. Those arrested were deported to Malta. ${ }^{28}$ The Kemalists in Anatolia retaliated by arresting all British officers and personnel in the provinces under their control. Colonel Rawlinson was amongst those arrested in Erzurum.

From this date until November 1921 he remained in prison. After his release under an Exchange of Prisoners agreement, he came back to London on 24 November 1921.

\section{Rawlinson's World:}

And finally, a few words about Rawlinson's world, or rather the world as it was described by Rawlinson.

Rawlinson was a typical 'Great Game' player. His contemporaries describe him as a "charming officer" who liked "more important and dangerous work". "A personality of...unusual type", and a "gentleman adventurer".

Admiral Sir Percy Scott, who wrote the General Introduction to Rawlinson's memoirs, describes him as an amazing adventurer who was "the most daring of fliers". ${ }^{29} \mathrm{He}$ further comments on Rawlinson by saying the following: "I could not have had a more charming officer to deal with; the more difficult the job I gave him the more he seemed to like it."30

The world, described by Rawlinson and those who shared his adventures, appears to be so completely satisfying that it remains more real to them than anything in normal/civilian life. In contrast to real life which is complex, confusing and without obvious mission, the war was a time when frontiers still existed. And the individual's social role was both clear and

${ }^{27}$ The British F.O. mentioned this as a strong possibility in an earlier despatch, on 6 March 1920, to their High Commissioner, which arrived in Constantinople on the next day. (Cambridge, Churchill College Archive Center; De Robeck Papers DRBK 6/4.)

${ }^{28}$ Cambridge, Churchill College Archive Center; De Robeck Papers, DRBK $6 / 1$. For the list of those arrested and subsequently deported to Malta see London, PRO; E 2805/37/44 and E 4395/37/44.

29 Ibid., p. 13.

${ }^{30}$ Ibid., pp. 13-14. 
consistent with naive patriotic impulses. The common faith was patriotism, the commonly accepted task was to defeat the 'enemy'.

The simplicity and clarity of the wartime situation make it analogues to the ideal world of childhood. When Colonel Rawlinson, Major-General Dunsterville, or Admiral Sir Percy Scott refer to each other they say "boys" and use sobriquets from children's magazines.

Rawlinson's interpretation of the contemporary political situation is one that would have been shared by most products of the public schools of his generation: East, "the land of ignorant Oriental populations". ${ }^{31}$ In a sense, Rawlinson's Turks were a pathetic people whose brilliance reveals nothing but their own emptiness. He was convinced that he was there "to make the Turk smell hell". 32 The Turks were simply the "cunning old barbarians". ${ }^{33}$ Even his faithful dog, 'George', was surprised when he saw the British sailors at the end of the captivity, because they "were so kind and friendly", "they were evidently not Turks".34

Other nations in the region were even less appealing than the Turks. Rawlinson's Tatars were "bloodthirsty" animals ${ }^{35}$, and Persians were uncivilised barbarians. "The most striking part of this old country [Persia]", he says, "is the absence of any change or progress". ${ }^{36}$ The Persian national characteristic was, according to Rawlinson, "Persian's indifference to suffering in others". ${ }^{37}$ The "Persian, like many of his Eastern neighbors, has a weakness for letting off his rifle at odd times, for no particular purpose except to let all and sundry know he has one". ${ }^{38}$ We also learn from Rawlinson of "a [Persian] mother eating her child". 39

Rawlinson's descriptions of the Armenians are the bleakest and most despairing of any that appear in his memoirs. However, there was "an Armenian [officer], and the only one of that race for whom" he had "...entertained any respect". 40

\footnotetext{
${ }^{31}$ Ibid., p. 307.

32 Ibid., p. 16.

33 Ibid., p. 339.

34 Ibid., p. 353.

35 Ibid., p. 93.

${ }^{36}$ Ibid., p. 55.

37 Ibid., p. 53.

${ }^{38}$ Ibid.

${ }^{39}$ Ibid., p. 54.

40 Ibid., p. 74.
} 
Once he was arrested Rawlinson the agent was transformed from hero to victim. The prison experience left him with his health impaired for life. After repatriation, with no war to fight, without a seat in Parliament, and with the British imperial system dissolving, Rawlinson's career had come to an end. He was left with no better prospects for the future than being paid "by his grateful country... 57s. $81 / 2 \mathrm{~d}$. per week for a limited number of months only". He was refused any kind of compensation either for his imprisonment or for the loss of his property, and he was "recommended to apply to the nearest Labour Exchange!"41

$$
\text { * } \quad \text { * } \quad \text { * }
$$

It is clear that Rawlinson's mission did not bring any successful result. Although his memoirs are full of small success stories, heroic actions, such as capturing a Soviet ship protected by ninety-six armed Bolsheviks with only ten British soldiers ${ }^{42}$, neither in the Caucasus nor in the eastern Anatolia did the activities of Rawlinson and his men have any serious impact upon the course of those historic events. In the case of his attempts to convince Karabekir to act against the Bolsheviks Rawlinson's activities even had a negative impact. However, he could not be blamed for failure of his missions. As we have seen he was an amazingly colourful character, and had all the necessary qualities for the job assigned to him. Nevertheless, the general conditions of the post-war period were not so opportune for the British. Without being supported by British military force and clear and decisive political decisions, covert Intelligence activities were bound to remain as interesting but ineffective trifles, perhaps only meaningful to those who had participated in them.

${ }^{41}$ Ibid., p. 14

${ }^{42}$ Ibid., p. 105. 